May 1999 • NREL/CP-520-25725

\title{
Update on the Million Solar Roofs Initiative
}

C. Herig

Presented at the National Center for Photovoltaics Program Review Meeting Denver, Colorado

September 8-11, 1998

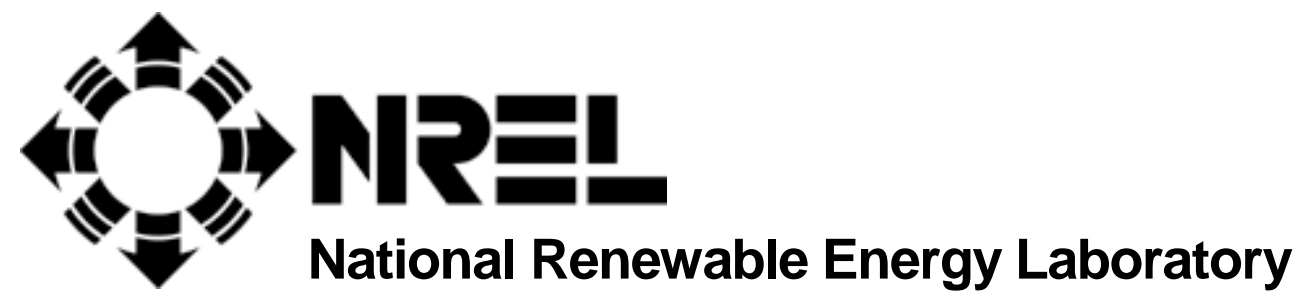

1617 Cole Boulevard Golden, Colorado 80401-3393

NREL is a U.S. Department of Energy Laboratory Operated by Midwest Research Institute $\bullet$ Battelle $\bullet$ Bechtel Contract No. DE-AC36-98-G010337 


\section{NOTICE}

This report was prepared as an account of work sponsored by an agency of the United States government. Neither the United States government nor any agency thereof, nor any of their employees, makes any warranty, express or implied, or assumes any legal liability or responsibility for the accuracy, completeness, or usefulness of any information, apparatus, product, or process disclosed, or represents that its use would not infringe privately owned rights. Reference herein to any specific commercial product, process, or service by trade name, trademark, manufacturer, or otherwise does not necessarily constitute or imply its endorsement, recommendation, or favoring by the United States government or any agency thereof. The views and opinions of authors expressed herein do not necessarily state or reflect those of the United States government or any agency thereof.

Available to DOE and DOE contractors from:

Office of Scientific and Technical Information (OSTI)

P.O. Box 62

Oak Ridge, TN 37831

Prices available by calling 423-576-8401

Available to the public from:

National Technical Information Service (NTIS)

U.S. Department of Commerce

5285 Port Royal Road

Springfield, VA 22161

703-605-6000 or 800-553-6847

or

DOE Information Bridge

http://www.doe.gov/bridge/home.html

Printed on paper containing at least $50 \%$ wastepaper, including $20 \%$ postconsumer waste 


\title{
Update on the Million Solar Roofs Initiative
}

\author{
Christy Herig \\ National Center for Photovoltaics, National Renewable Energy Laboratory \\ 1617 Cole Blvd, Golden, Colorado 80401
}

\begin{abstract}
The Million Solar Roofs Initiative, announced by the President in June of 1997, spans a period of twelve years and intends to increase domestic deployment of solar technologies. This paper presents an overview of the development of the initiative and significant activities to date.
\end{abstract}

\section{INTRODUCTION}

The energy utility industry is making the transition from being a regulated monopoly to working in a competitive environment. As a result, responsibility for energy-related public services is shifting to state legislative policy and to community (regional or municipal) programs. The Million Solar Roofs (MSR) Initiative provides high-value solutions, such as distributed generation, for community-based energy infrastructure, environmental protection, and economic development planning.

The gradual national implementation and community participation in the MSR Initiative is planned to result in one million installations by 2010 and seeks to achieve the national goals of:

- Reducing greenhouse gas and other emissions (over 3.5 million tons of $\mathrm{CO}_{2}$ annually by 2010 , equivalent to 850,000 automobiles)

- Create high-tech jobs (over 70,000 by 2010)

- Keep the U.S. solar industry competitive.

These million installations, amounting to over 3,000 megawatts (MW) of solar capacity (PV and thermal), should also help communities meet goals similar to the national goals. At the state and community levels, comprehensive plans include infrastructure elements such as parks and recreation, land use, air quality, water quality, and transportation. Integrating renewable energy with existing elements and as additional infrastructure elements can aid communities in meeting the growth and action targets of comprehensive plans.

The Million Solar Roofs Initiative will be coordinated with federal and local enterprise and empowerment programs. The technology's modularity should entice 
continued solar-related business development in the new energy industry. The initiative also targets utility involvement, with certain aspects modeled after the Sacramento Municipal Utility District (SMUD) "PV Pioneer" program.

\section{BACKGROUND}

The premises for the initiative are strongly based on results and impacts developed in the U.S. Department of Energy commercialization project PV:COMPACT (Photovoltaic Collaborative Market Project to Accelerate Commercial Technology). The multiple facets of PV:COMPACT have addressed the transitioning utility industry, the PV manufacturing industry, market value, barrier analysis, and community policy development and valuation.

The Utility Photovoltaic Group (UPVG) has developed utility partnerships and experience $^{1}$ through the TEAM-UP program-Technology Experience to Accelerate Markets in Utility Photovoltaics. Codes and standards, required for building construction integration and financing, have evolved. The PV industry has also recently integrated PV into commonly used building products such as PV shingles, PV-surfaced insulated flattop roof tiles, solar facades, and PV curtain walls. Photovoltaic module shipments have steadily increased by $15 \%$ over the past 12 years. Figure 1 shows a conservative projection for future manufacturing capacity resulting from an annual growth range between $10 \%$ and $15 \%$. Though international markets will continue to demand most of this capacity, the Million Solar Roofs Initiative will ensure that a portion of this clean energy resource remains in the United States.

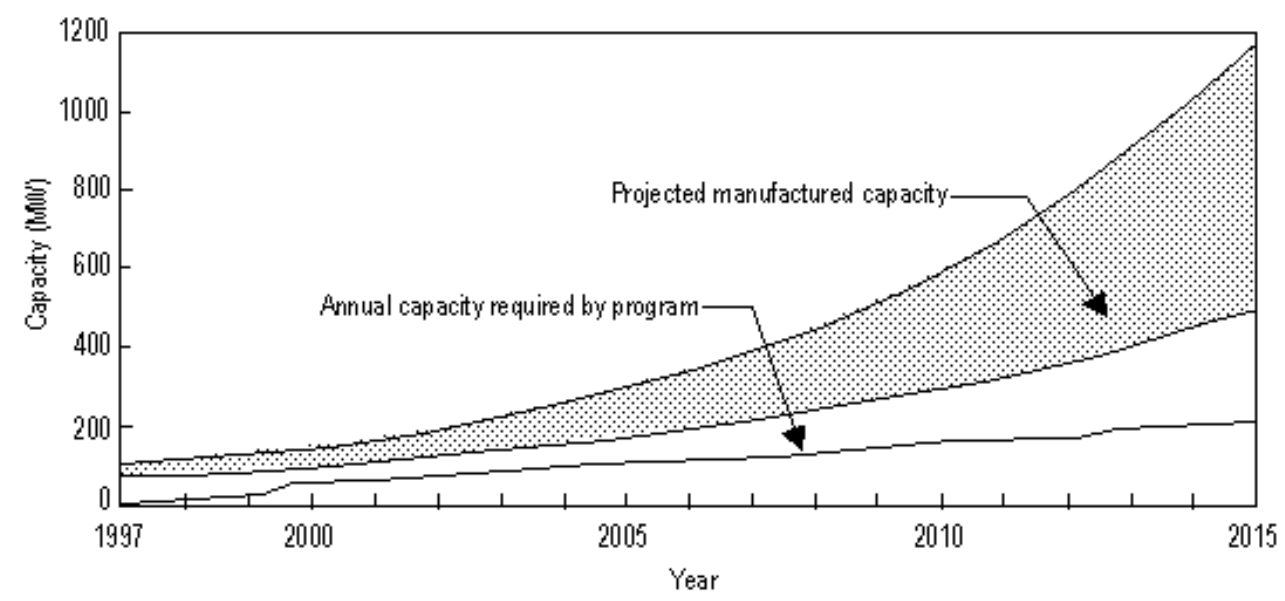

Figure 1. Manufacturing Capacity vs. MSRI Roofs Annual Requirement The shaded envelope is bounded by annual growth of $10 \%$ (lower bound) and of $15 \%$ (upper bound).

\footnotetext{
${ }^{1}$ These partnerships include the SMUD program and diffusion of this program to other municipal utilities.
} 
Solar technologies have a higher price relative to central-station fossil-fuel generation. MSR provides an alternative, higher-value market arena at the state, community, and consumer level. The solar-technology attributes of consumer preference, environmental impact mitigation, distributed resource, and building integration can combine at the state and local level to result in deployment value.

The basic elements of the Million Solar Roofs Initiative were developed as a result of analytic support of the myriad regulatory actions and energy policies evolving across the nation. Hence, it is flexible and easily adapted to most community-based policy. The initiative provides high return value for the full range of solar-related policies: capital buy-downs, restructuring policies (set-asides or portfolio standard), state tax credits, utility tax exemptions, net metering, low-interest loans, property tax exemptions, manufacturing grant incentives, utility infrastructure reserves, and energy production incentives. The initiative both enhances and complements implementation value, but does not depend on the availability of all policies for a community to successfully participate.

The President announced the MSR initiative in June of 1997, and within a few months, nine communities came forward with deployment plans and letters of commitment totaling over half of the targeted million installations. These communities and their stated commitments are listed below:

- New England Electric Service

100,000

- Maryland Energy Administration

20,000

- State of Colorado

- Salt River Project 20,000

- Tucson Electric Power Company 400

- Hawaii Electric Light Company 20,000

- Washington State Solar Energy Industry Association 20,000

- Sacramento Municipal Utility District

Within service territory

25,000

Throughout California

20,000

- Los Angeles Department of Water and Power

100,000

- Federal Commitment

20,000

The deployment teams involve one or more stakeholders, noted in Figure 2. A lead stakeholder from each community team coordinates value identification, infrastructure development, and education activities. Even though most of these communities are areas of high PV market value, PV still has a higher cost than conventional utility grid electricity. In 2010, installation of one million solar roofs will be less than one-percent saturation, according to the U.S. Census Bureau projection of total households. The Initiative's goal to deploy this relatively new, energy-producing, "solar roof" consumer 
product requires community teams to identify and couple stakeholder values to overcome the cost barrier. Figure 2 associates a dollar-per-watt range of values for each

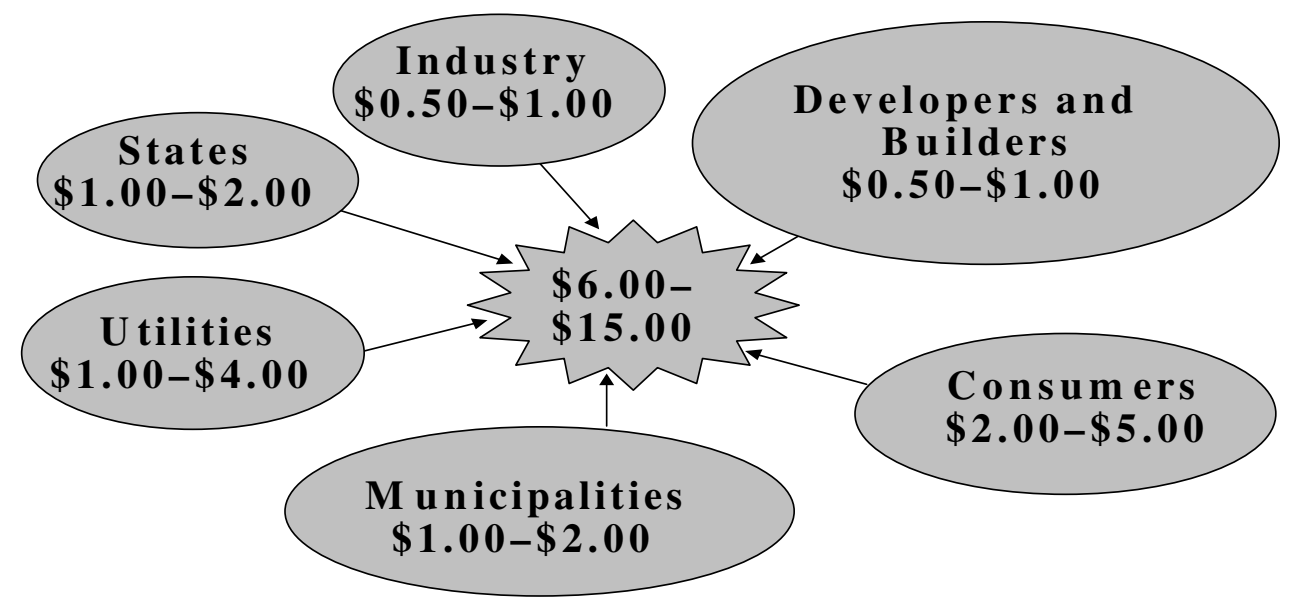

Figure 2. Community team stakeholders and and ranges of dollar-per-watt capital value.

stakeholder category within the community team. Though not all of the values have been realized in actual deployment, support analysis is available. The following subsections will describe analysis and activities that support the community team values.

\section{States}

As states set up mechanisms to transition their utilities to the more competitive restructured arena, many opportunities arise that are favorable to renewables and, in many cases, specifically solar. System benefit charges and renewable portfolio standards are two common policies resulting in funding or investment in renewables.

The system benefit charge (SBC) is a mechanism for the state to collect a percent of the electricity rate, based on use to fund public benefits lost without regulatory protection. In California, the SBC included funding for R\&D, efficiency, low-income, and renewables programs. The California SBC value to the solar consumer is $\$ 3$ per watt. $^{2}$ Though the SBC is typically only $5 \%$ of the total restructuring funding going to stranded debt, ${ }^{3}$ these funds are substantial for the solar industry, as noted in Table 1.

\footnotetext{
${ }^{2}$ The California program provides a consumer buy-down of about $\$ 3 / \mathrm{W}$ (declining over the 4-year period) up to $50 \%$ for grid-connected systems.

${ }^{3}$ In California, the SBC portion of the total competitive transition charge of over $\$ 30$ billion will amount to about 1.3 billion.
} 
Table 1

\begin{tabular}{|c|c|}
\hline SBC in 1998 & Future SBC \\
\hline $\begin{array}{l}\text { California - } \$ 10.5 \text { million ( } \$ 54 \text { million } \\
\text { over } 4 \text { years) }\end{array}$ & Illinois - $\$ 5$ million annually (10 years) \\
\hline New York - $\$ 5$ to $\$ 7$ million & $\begin{array}{l}\text { Massachusetts - \$20 to } 26 \text { million (5 } \\
\text { years) }\end{array}$ \\
\hline Rhode Island - $\$ 0.25$ to 0.7 million & Montana - \$1 million (all renewables) \\
\hline Wisconsin $-\$ 0.035$ million & $\begin{array}{l}\text { Connecticut - } \$ 14 \text { million, (2000) and } \\
\$ 70 \text { million (2001-2004) }\end{array}$ \\
\hline & Pennsylvania - \$12 million (PECO) \\
\hline
\end{tabular}

The renewable portfolio standards require the energy service providers in the state to have a portion of the energy sold to be provided by renewables. The energy providers may choose to purchase the energy or invest in the renewable generation, but the end product is solar technology deployment. Arizona is a state that has instituted a solar portfolio standard. Analytic support for developing the standard indicated the benefits to the state noted in Table 2 below.

Table 2

\begin{tabular}{|l|c|}
\hline \multicolumn{2}{|c|}{ Initial Arizona Solar Portfolio Standard Analysis } \\
\hline Jobs created by 2010 & 600 jobs \\
\hline Wage, salary, and state income tax & $\$ 200$ million \\
revenue (1998-2020) & \\
\hline $\begin{array}{l}\text { Global warming, } \mathrm{CO}_{2} \text {, emissions avoided } \\
\text { (by 2020) }\end{array}$ & 12 million tons \\
\hline Acid rain, $\mathrm{S}_{\mathrm{ox}}$ emissions avoided & $\$ 120$ million \\
(by 2020) & 32,000 tons \\
\hline SMOG, $\mathrm{N}_{\text {ox }}$ emissions avoided & $\$ 85$ million \\
(by 2020) & 38,000 tons \\
\hline
\end{tabular}

\section{Municipalities}

In addition to the environmental and economic development values realized by the states, municipalities can take advantage of disaster mitigation values and aggregated services with solar policy. Cities are accustomed to funding high-capital-cost infrastructure such as roads, sewers, and water supplies. Mechanisms such as 
infrastructure reserve funds, ${ }^{4}$ management districts, ${ }^{5}$ development impact fees, and short-term sales tax increases, all collect funds for high-capital expenditures. Municipalities can also act as an aggregated customer, with service requirements through the utility franchise agreement. Many municipalities have high electricity rates that, when coupled with solar policies, result in cost-effective applications. Table 3 below shows 20 cities with high energy costs and the impact on the consumer's monthly cash flow of a buy-down and low-interest financing.

When multiple commercial and political interests team together, the overall value of solar technologies increases. The community partnership team is the current approach for the Million Solar Roofs Initiative. Though only nine communities have documented deployment plans, these plans represent over half of the goal, and there are more than 30 other communities developing teams and action plans. In addition to the two community team values detailed in this paper, Table 4 below indicates value areas to other community team partners in the initiative.

The MSR Initiative will initially depend on restructuring policy funding. However, as the energy service providers complete the transition to a semi-regulated business environment, communities will be the sustaining force to couple stakeholder values and deploy solar technologies.

\section{ACKNOWLEDGEMENTS}

This work was funded by the U.S. Department of Energy, through the National Center for Photovoltaics. Special thanks go to Roland Hulstrom, Carol Tombari, and John Thornton of the National Renewable Energy Laboratory; Howard Wenger of Pacific Energy Group; and Chris Cameron and Roger Hill of Sandia National Laboratories.

\section{REFERENCES}

1. Wenger, H. and others, "Policy Options to Accelerate Grid-Connected Markets," presented at the American Solar Energy Society's Solar '97 conference, Washington, D. C., April 1997.

\footnotetext{
${ }^{4}$ A water-supply infrastructure reserve fund would collect a fee based on use from consumers to fund future capital infrastructure expenditures. Germany's and Switzerland's rate-based incentives are examples of a renewable-energy infrastructure mechanism.

${ }^{5}$ San Diego has recently set up a regional energy office with the intent of being an energy management district.
} 
Table 3

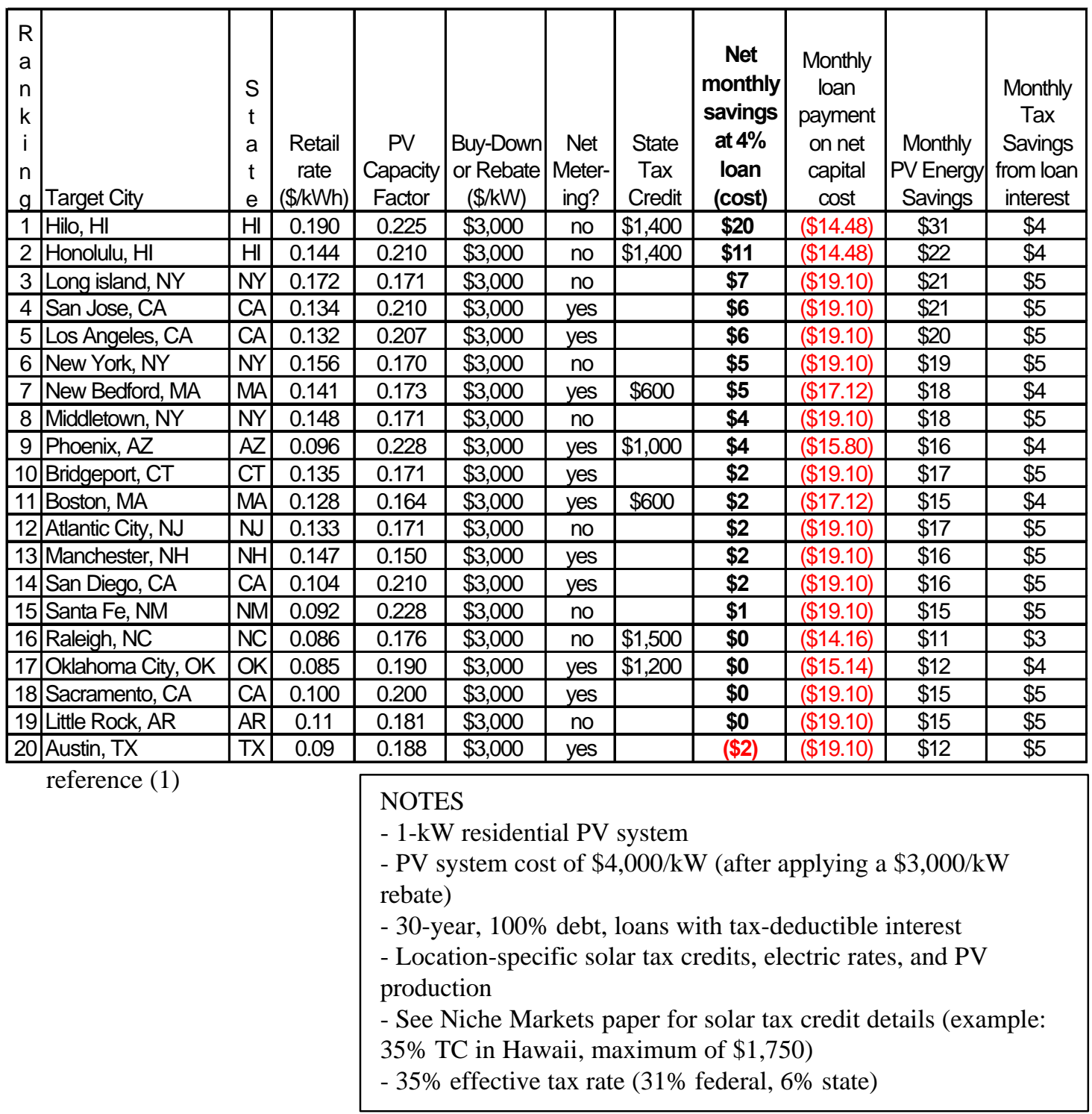


Table 4

\begin{tabular}{|l|l|}
\hline Team Member Category & Justification Values \\
\hline Utility-IOU, municipal, REA, & Distributed resource \\
Cu-OP, PA, ESCO & Financial risk mitigation \\
& Developing competitive business opportunity \\
Effective load carrying capacity
\end{tabular}




\section{REPORT DOCUMENTATION PAGE}

Form Approved

OMB NO. 0704-0188

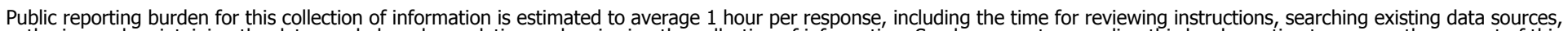

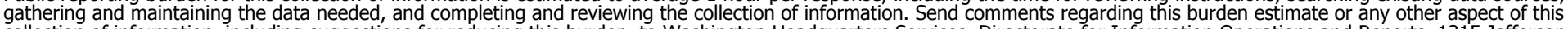

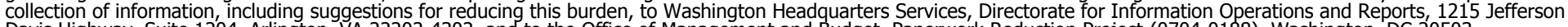

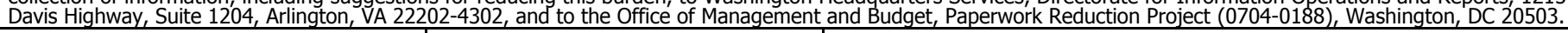

\begin{tabular}{|l|l|l|l}
\hline 1. AGENCY USE ONLY (Leave blank) & $\begin{array}{l}\text { 2. REPORT DATE } \\
\text { May } 1999\end{array}$ & $\begin{array}{l}\text { 3. REPORT TYPE AND DATES COVERED } \\
\text { Conference Paper }\end{array}$ \\
\hline 4. TITLE AND SUBTITLE &
\end{tabular}

Update on the Million Solar roofs Initiative

6. AUTHOR(S)

C. Herig

5. FUNDING NUMBERS

$\mathrm{C}$ :

TA: PV908103

7. PERFORMING ORGANIZATION NAME(S) AND ADDRESS(ES)

National Renewable Energy Laboratory

8. PERFORMING ORGANIZATION

1617 Cole Blvd.

REPORT NUMBER

Golden, CO 80401-3393

9. SPONSORING/MONITORING AGENCY NAME(S) AND ADDRESS(ES)

10. SPONSORING/MONITORING

AGENCY REPORT NUMBER

CP-520-25725

\section{SUPPLEMENTARY NOTES}

12a. DISTRIBUTION/AVAILABILITY STATEMENT

National Technical Information Service

12b. DISTRIBUTION CODE

U.S. Department of Commerce

5285 Port Royal Road

Springfield, VA 22161

13. ABSTRACT (Maximum 200 words)

The Million Solar Roofs Initiative, announced by the President in June of 1997, spans a period of twelve years and intends to increase domestic deployment of solar technologies. This paper presents an overview of the development of the initiative and significant activities to date.

14. SUBJECT TERMS

photovoltaics ; Million Solar Roofs Initiative ; domestic applications ; stakeholders

17. SECURITY CLASSIFICATION

OF REPORT

Unclassified
18. SECURITY CLASSIFICATION

OF THIS PAGE

Unclassified
19. SECURITY CLASSIFICATION

OF ABSTRACT

Unclassified
15. NUMBER OF PAGES

9

16. PRICE CODE

NSN 7540-01-280-5500

Standard Form 298 (Rev. 2-89) Prescribed by ANSI Std. Z39-18 